\title{
Student-centred approach to teaching large classes: friend or foe?
}

\author{
Marina Kirstein and Rolien Kunz \\ Department of Auditing, University of Pretoria, Pretoria, South Africa
}

\begin{abstract}
Purpose - The aim of this paper is to report on the development and implementation of two student-centred teaching approaches, not usually thought to be appropriate for large group situations. These projects involved adapting teaching methods to facilitate a move away from the conventional lecturer-centred approach (the "chalk-and-talk" of earlier generations) and to respond to an environment challenged by the perpetually changing requirements of professional bodies, increasingly large classes and high student-staff ratios.

Design/methodology/approach - Two student-centred projects were implemented at a South African residential university in the discipline of auditing, and the topic of general controls in the information technology (IT) environment was addressed. This study reports on two cycles of the development and implementation of the projects following an action research methodology.

Findings - It was found that "non-standard" teaching practices can be implemented successfully and that active student involvement, even in a large class environment, is achievable and is therefore recommended, not least because this could positively impact on students' overall skills development. The action research methodology was successfully used to incorporate changes, enforced by the challenges accounting academics are faced with.
\end{abstract}

Research limitations/implications - Limitations associated with this study are that it was conducted at only one South African university, and that it was in a specific and technical topic within the single field of auditing. The study also did not measure whether deep or surface learning had taken place. As various factors contribute to learning, it was also not possible to report on whether positive changes to students' normal learning processes have been achieved as a result of the initiatives. Originality/value - The contribution this study makes is twofold. First, it adds to the field of accounting education research by indicating that student-centred projects can successfully address the abovementioned challenges faced by accounting academics. Second, it demonstrates that action research, as a methodology for examining and developing accounting education, can be used effectively by academics to improve their teaching practices.

Keywords Action research, Accounting education, Qualitative research, Pedagogy, Auditing, Lecture-centred approach, Student-centred approach

Paper type Research paper

\section{Introduction}

"This is the revolution of you, me, and the person next door [...]" (Grulke, 2000). We live in a world where, as popular wisdom has it, "the only constant is change" (Slabbert et al., 2009), and the academic sphere (including accounting academics) is in no way exempt from this force. Academics, in general, face numerous challenges, and the most pertinent facing accounting educators, particularly in South Africa, arise from the dynamic nature of the requirements and expectations of professional bodies (Barac, 2009; De Lange, 
Marx and Van der Watt, 2013), the adjustments to teaching approaches necessitated by the fundamentally different mindset of a new generation of students (Booysen, 2013; Feiertag and Berge, 2008; Jukes and Dosaj, 2006; Kane, 2013) and the changing demands of the academic environment (Brew, 2003; Elton, 2001; Evans et al., 2010; Perera, 2012). Professional bodies continuously develop their competency frameworks in response to the changing business environment, which, in turn, now requires that accounting students should not only obtain technical knowledge but also that they should develop a range of professional, workplace-appropriate skills, as part of their tertiary education (Barac, 2009; Crawford et al., 2011; De Lange et al., 2013; Howieson et al., 2014; Keneley and Jackling, 2011; Low et al., 2013). Even though such professional competency frameworks identify the competencies which should be acquired through academic and training programs, very little guidance is provided as to the most effective teaching approaches that could be followed (SAICA, 2010). Today's students, the so-called generation Y (Booysen, 2013; Feiertag and Berge, 2008; Jukes and Dosaj, 2006; Kane, 2013) (those who have been born into a technology-rich environment), are known to be very demanding, but they are also potentially very productive (Booysen, 2013; Kane, 2013), which poses a challenge to accounting educators still employing traditional teaching practices. The teaching environment facing accounting academics is also changing. They are faced with increasing numbers in their classes (500 students in a lecture is not abnormal); there is pressure to balance teaching and research responsibilities; the student-staff ratios are rapidly escalating and an ageing faculty is resistant to untested change (Brew, 2003; Elton, 2001; Evans et al., 2010; Herington and Weaven, 2008; Paisey and Paisey, 2005; Perera, 2012).

The research literature, in general, endorses a student-centred approach and acknowledges the necessity of adapting teaching methods to better address the challenges of equipping the new generation of students with the necessary accounting skills (Cooper and Robinson, 2000; Killen, 2010). There is also support for the notion of moving away from traditional teaching practices (Doolittle and Camp, 1999; Killen, 2010; Samkin and Francis, 2008; Steffe and Gale, 1995) and for the development and adoption of innovative teaching initiatives.

The aim of this paper is to report on the development and implementation of two student-centred teaching approaches, not usually thought to be appropriate for large group situations. These projects involved adapting teaching methods to facilitate a move away from the conventional lecturer-centred approach (the "chalk-and-talk" of earlier generations) and to respond to an environment challenged by the perpetually changing requirements of professional bodies, increasingly large classes and high student-staff ratios.

Action research was the preferred research methodology, a relatively unexplored and under-utilised research methodology in accounting education research (Hazelton and Haigh, 2010; Paisey and Paisey, 2005). The contribution this study makes is therefore twofold. First, it adds to the field of accounting education research by indicating that student-centred projects can successfully address the abovementioned challenges faced by accounting academics. Second, it demonstrates that action research, as a methodology for examining and developing accounting education, can be used effectively by academics to improve their teaching practices.

The two student-centred projects were implemented at a South African residential university in the discipline of auditing, and the topic of general controls in the 
information technology (IT) environment was addressed. This study reports on two cycles of the development and implementation of the projects. During the first action research cycle, two student-centred projects were implemented. The first project involved presentations by the students, and the second a simulation of a real-life audit environment. At the end of the first cycle, the authors, together with colleagues who had acted as peer-reviewers (and were present in the sessions), and students through evaluation questionnaires, reflected on the projects to improve them for the second action research cycle. Thereafter, based on these reflections, it was decided that only one of the student-centred projects, namely, the simulation of the real-life environment, should be repeated. This study reports on the implementation of these two approaches, and it concludes with reflections on the exclusive use of the second project in the second cycle.

It was found that "non-standard" teaching practices can be implemented successfully even in large classes with high student-staff ratios, and that active student involvement, even in a large class environment, is achievable and is therefore recommended, not least because this could positively impact on students' overall skills development.

The remainder of the paper is structured as follows. The literature is reviewed to contextualise the study and achieve an understanding of action research. Thereafter, the background to the study is outlined, and the action research project is presented. The results are then discussed, and the paper concludes with an assessment of the limitations of this research project and recommendations for future research.

\section{Literature review}

The literature supports the notion that today's accounting academics are facing multiple challenges (Brew, 2003; Elton, 2001; Evans et al., 2010; Perera, 2012). These challenges can be grouped into three themes. First is the external environment, which includes the expectations and requirements of professional bodies and potential employers (Barac, 2009; De Lange et al., 2013). Second is the internal environment, which includes large class enrolments, high student-staff ratios (Cooper and Robinson, 2000; Evans et al., 2010), a new generation of students (Booysen, 2013; Feiertag and Berge, 2008; Jukes and Dosaj, 2006; Kane, 2013) and an ageing faculty that is resistant to untested change (Brew, 2003; Elton, 2001; Evans et al., 2010; Herington and Weaven, 2008; Paisey and Paisey, 2005; Perera, 2012). Third, there is the need for academics to balance teaching and research responsibilities (Brew, 2003; Elton, 2001; Evans et al., 2010; Samkin and Schneider, 2014a, 2014b).

Employers of prospective accounting students are placing increasing pressure on academics to equip accounting graduates with not only technical knowledge but also with a range of skills and attributes appropriate to the professional work environment they are about to enter (Barac, 2009; De Lange et al., 2013). In response to these employer requirements, professional bodies have developed competency frameworks, identifying a broad range of technical knowledge components, skills and attributes that higher education institutions are expected to embed in accounting graduates before they enter the profession (Barac, 2009; Boritz and Carnaghan, 2003; Palmer et al., 2004). To meet the expectations and requirements of professional bodies, accounting academics can no longer include only technical knowledge in their teaching practices; they have to teach soft skills as well (De Villiers, 2010; Low et al., 2013). 
In a study entitled Accounting Education at a Crossroad, published by the Institute of Chartered Accountants in Australia in 2010, a number of challenges to the higher education sector were highlighted (Evans et al., 2010). The challenges most pertinent to this research included large classes with high student-staff ratios, heavy teaching and preparation loads, increased levels of administration and limited time and support for research (Brew, 2003; Elton, 2001; Evans et al., 2010). Perera's (2012) study indicated that in New Zealand, the challenge faced by accounting academics lies in the imbalance between rewards for time spent teaching in comparison to that spent on research. Academic advancement remains heavily weighted in favour of published research, to the detriment of teaching activities (Perera, 2012).

Students and their parents, however, view education as an investment and are therefore searching for higher education institutions that will not only prepare them for employment but will significantly enhance their perceived market worth (Abeysekera, 2006; De Lange et al., 2013). It is this parental and societal expectation that accounting and auditing are sure paths to economic wealth that is probably behind the apparent disconnect between "boring", old style, lecture-centric courses (which would normally be the course's death-knell) and the excessively large classes that materialise each year. According to Cooper and Robinson (2000) and Evans et al. (2010), large classes are a reality in undergraduate accounting courses and this situation will continue to intensify into the foreseeable future. A lecturer-centred approach is predominantly used in large class environments (Cooper and Robinson, 2000), usually for administrative and other "practical" reasons. Large class environments themselves present many challenges, not least being the need to maintain a current relevance to course content, while simultaneously accommodating the diverse learning styles used by the students in these large classes (Herington and Weaven, 2008; Stork, 2003).

The student mental profile has also changed over the years (Booysen, 2013; De Lange et al., 2013; Kane, 2013), adding to the challenges faced by higher education institutions. Today's young people, also known as generation Y, are fundamentally different from previous generations in outlook and in the way they learn (Booysen, 2013; Feiertag and Berge, 2008; Kane, 2013; Slabbert et al., 2009). The learning style of the modern student is hands-on and not automatically linear (Booysen, 2013; Feiertag and Berge, 2008; Kane, 2013). Lecturing to this electronic-communication-device-dependent generation is becoming increasingly obviously ineffective, and accounting academics have to move away from the traditional lecturer-centred approach to accommodate this new generation's preference to learn through play (Booysen, 2013; Feiertag and Berge, 2008; Kane, 2013), particularly as they get bored very quickly (Booysen, 2013; Kane, 2013). Accounting academics therefore need to find innovative ways to equip this new generation of students with the technical knowledge and professional skills required by future employers and professional bodies, without losing their attention along the way. The move away from the lecturer-centred approach in large class environments therefore holds profound implications for accounting academics, especially in the way skills and accounting literacy are transferred (Barac, 2009; De Lange et al., 2013; Evans et al., 2010).

A lecture-centred approach to teaching, which is also known as direct instruction (the "chalk-and-talk" method of earlier generations), is characterised by a lecturer taking direct control of the class (Killen, 2010). In this type of lecture, the focus is on the lecturer, and the students are not compelled to be actively involved in the learning process 
(Cooper and Robinson, 2000; Killen, 2010). It was found that a lecturer-centred approach transfers information less efficiently, and is less effective in the long term than more interactive and participatory methods, as students generally only remember 10-20 per cent of what they hear (Biggs, 2000; Cooper and Robinson, 2000; Cunningham, 2008; Killen, 2010). The student-centred approach (in many ways, the antithesis of the lecturer-centred approach) has proved to be a more effective way of transferring skills and literacy to new generation students (Cooper and Robinson, 2000; Killen, 2010) in that it gets them actively involved in the learning process.

In a student-centred approach, the focus is on the students who are actively involved in driving the learning process, and the lecturer has less direct control over what and how the students learn (Killen, 2010). It should be noted that the constructivist learning theory forms the foundation for the development of a student-centred approach (Baeten et al., 2010) in that activities are presented in such a way that students are then able to actively construct knowledge, and not just absorb it (Killen, 2010). Lecturers act as agents of transformation, enabling students to interpret and construct their own knowledge (Biggs, 2000). Sound teaching is no longer about assisting learners to accumulate knowledge that is passed on to them by the teacher and/or their textbooks. It is about assisting learners to make sense of new information (no matter what its source), to integrate new information into their existing ideas, to be aware of their thinking and learning processes and to apply their new understanding in meaningful and relevant ways (Doolittle and Camp, 1999; Killen, 2010; Samkin and Francis, 2008; Steffe and Gale, 1995). This mind-shift from a lecturer-centred approach to a student-centred approach can be achieved by various teaching methods that have been developed over time (Baeten et al., 2010; Killen, 2010) in diverse disciplines and which include experiential learning and cooperative learning, amongst others.

Learning arises through exposure to real-life challenges, also referred to as experiential learning (Slabbert et al., 2009; Gentry, 1990). Including experiential learning in lecturing practices provides students with the opportunity to learn-by-doing (Rudman and Terblanche, 2011; Wynder, 2004), enhancing the students' understanding of the subject matter in the process (Massey et al., 2002). Learning is more effective when simulations are used because it is integrated within a real-world situation or context (Kastantin and Novicevic, 2008; Rudman and Terblanche, 2011; Wolmarans, 2005). A real-world environment creates a platform for the development of both technical knowledge and the skills required by professional bodies (Rudman and Terblanche, 2011; Wessels and Steenkamp, 2009).

Cooperative learning (the second technique investigated for this research paper), is a technique in which learners work together in small groups, ostensibly to facilitate and support one another's learning (Ballantine and Larres, 2009; Ballantine and Larres, 2007; Killen, 2010). A cooperative learning environment exists if the five basic elements of co-operative learning are present (Ballantine and Larres, 2009; Ballantine and Larres, 2007). These elements are positive interdependence, individual accountability, face-to-face interaction, development of social skills and monitoring of small group skills and group performance (Aziz and Hossain, 2010; Ballantine and Larres, 2009; Ballantine and Larres, 2007; Johnson and Johnson, 1987; Kunkel and Shafer, 1997). Individual accountability was noted by Kunkel and Shafer (1997) as an important part of cooperative learning in that it formally transfers the responsibility for what the individual students achieve to the students themselves. There is growing consensus 
among researchers about the positive effects of co-operative learning on student achievement (Aziz and Hossain, 2010; Ballantine and Larres, 2009; Ballantine and Larres, 2007; Johnson and Johnson, 1987; Slavin, 1996). In that students learn from one another by hearing, thinking about and reasoning through opposing points of view, also contributes to development of higher-order thinking (Cunningham, 2008). Studies conducted in accounting education have indicated that cooperative learning approaches are essential for the development of key professional skills in accounting students, as teamwork is considered to be very important by prospective employers (Ballantine and Larres, 2007; Barac, 2009; Bui and Porter, 2010; Gabbin and Wood, 2008; Hall et al., 2007).

\section{Action research}

Action research is a structured research approach to investigate the effect of change in a classroom environment, and it has commonly been used by educationalists to improve their practices (Hand, 2001; Jove, 2011; Leitch and Day, 2006; Reason and Bradbury, 2007; Webb and Scoular, 2011). Webb and Scoular (2011) used action research to examine the reflections of pupils about being "reflective learners", whilst Jove (2011) addressed the question: "How do I improve what I am doing as a teacher, teacher educator and action-researcher through reflection?" Action research is increasingly being promoted as a research method for use in a classroom environment, as educators do it by themselves, about themselves and for themselves (Bassey, 1998; McNiff, 2002; Paisey and Paisey, 2005, 2003).

Action research has already been used by educators as a methodology to evaluate and bring about changes to their teaching approaches (Cunningham, 2008; Paisey and Paisey, 2005, 2003). In accounting education specifically, action research has also been used as an approach to bring about positive change, through an iterative and reflective process (Baker and Logan, 2006; Hazelton and Haigh, 2010; Herington and Weaven, 2008; Kaplan, 1998; Paisey and Paisey, 2005, 2003).

Action research takes a spiral form, consisting of sequential cycles comprising the following four steps as indicated in Figure 1 (Altrichter et al., 2002; Hand, 2001; McNiff, 2002; Van Wyk, 2006):

(1) Planning to solve a problem or to implement a predetermined plan or process. This may include reflecting on current practices to identify areas in need of improvement and research into educational topics. The planning of the identified/needed change forms part of this step.

(2) Implementation of the previously determined plan or process emerging from Step 1.

(3) Observing the effects of the plan or process during its implementation. This can be done by various people and in various ways.

(4) Reflecting on the effects of the implemented plan or process, which have been observed in Step 3. The researchers interrogate and analyse the observations to draw practical conclusions, which then underpin the findings of the project.

Action research has its own limitations, which are classified either as control effects or as researcher effects (Mouton, 2012). The control effects include possibly overly broad 
Figure 1. The action research spiral

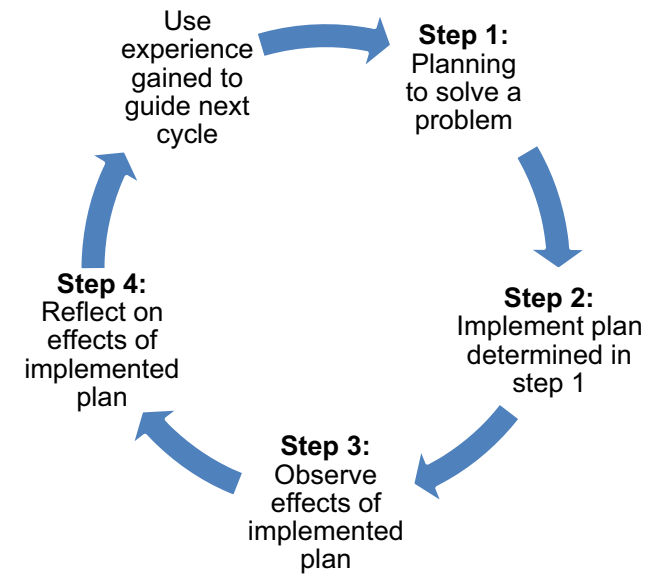

generalisations and conjecture as to causal and structural relationships made by the researchers. The researcher effects include the possibility of manipulation of the research process by the participants to serve their own interests that might include emotional and subjective involvement in the research process (Mouton, 2012). Both these effects can be countered by the collection and analysis of a variety of data from different sources (Herington and Weaven, 2008; Hermes, 1999).

French (2009) highlights that in traditional research methods, there is often a widely accepted and specific method of data collection that is symbiotic with the data analysis method; this is not generally the case in action research. Action research has as yet no unique or preferred method of data collection associated with it (French, 2009). However, in keeping with the principle of rigour in research, multiple sources of data and triangulation are usually encouraged (Cresswell, 2013; Jick, 1979). It has been suggested that questionnaires be used in the action research process, to give the process more "rigour" (Hand, 2001; Kember and Gow, 1992; Paisey and Paisey, 2005). Paisey and Paisey (2005) have also indicated that conversations with "critical friends" have assisted them in identifying issues and reflecting on insights arising from their action research projects. Herington and Weaven (2008) have also made use of the reflections of tutors in an action research project conducted to guide them in monitoring student engagement in a particular academic course.

The value of action research lies in the fact that it is a structured process that provides the researchers with insights to improve their practices. These insights arise through reflections, and through the collection and analysis of a diverse array of data (Herington and Weaven, 2008; Hermes, 1999). Reflection forms part of the data gathered during the action research process, and can be done during the action (as a record of real-time response to the action) and after the action has taken place (often a more considered and analytical data set) (Du Toit, 2012). As indicated by Zubert-Skeritt (1992) and Carr and Kemmis (1986), the experiences gained from the first cycle can be used to guide a second, third and even fourth cycle of action research.

Arising from an evaluation of the effectiveness of action research identified in the above literature the authors felt that action research would be an appropriate method to use in this study. 


\section{Background to the study - an audit perspective}

Every entity in the business world is exposed to business risks, risks that might compromise its efforts to meet its objectives. To minimise these business risks, management designs and implements policies and procedures (including internal controls) to assist the business to mitigate these risks as it strives to meet its objectives.

The internal controls consist of manual or IT controls or a combination of both. The study of manual controls forms part of the second-year auditing syllabus, while the internal controls in the IT environment form part of the third-year auditing syllabus. Controls in an IT environment are categorised as either general controls or application controls (Jackson and Stent, 2012).

Auditing is a compulsory subject that forms part of the BCom Accounting Sciences degree at the university where the study was performed, and both the second-year auditing and third-year auditing courses are full-year modules. At the time the two student-centred projects were implemented, both the authors taught third-year (undergraduate) auditing, and these projects formed part of their respective classes. These undergraduate-level lectures are presented at the university in both English and Afrikaans; one project was introduced by the lecturer responsible for the English-speaking group and the other project by the lecturer responsible for the Afrikaans-speaking group.

The practice at the university has been to present the topic of general controls in the IT environment in three, 2-hour long lectures per week. The teaching method uses a lecturer-centred approach to both the English and the Afrikaans groups. This approach typically involves direct instruction as its teaching strategy. Direct instruction involves the delivering of academic content in a structured format, in which students are expected to find, remember, understand and organise information and then demonstrate their understanding via examinations (Killen, 2010). Student participation is usually limited to informal question-and-answer sessions immediately after the lectures.

\section{The action research project}

The action research project will now be discussed, using the four steps in the cycle identified in the discussion of action research above.

\subsection{The first cycle - 2012}

5.1.1 Step 1: planning to solve a problem or to implement a predetermined plan or process. The authors' reflections on their current pedagogical practices led to the realisation that the various challenges they face are not unique. The challenges stem, in a large part, from the professional body's accreditation requirements for universities, which accounts for the large student groups, and high student-staff ratios (Brew, 2003; Elton, 2001; Evans et al., 2010; Perera, 2012). Previous students' evaluations of lecturers made it apparent that they found auditing lectures boring. Comments from a survey of third-year students' views confirm this:

The lecture is boring [...]. something should be done to improve that.

Need more practical and "real life" examples in class that are linked to the theory.

The subject is very difficult to understand when it comes to application; more time should be spent on application. 
The authors therefore decided to address this situation by implementing a student-centred approach to teaching. The intention was to get the students actively involved in the lectures and in addition to develop some of the professional (as opposed to technical and academic) skills as set out in the South African Institute of Chartered Accountants' (SAICA - the professional accrediting body) competency framework. The first 2-hour lecture was presented in the normal lecturer-centred manner during which the students were provided with background on the corporate IT environment and introduced to the most common types of general controls. Following the first lecture, the two student-centred projects were implemented.

Project 1 involved the 170 students of the Afrikaans-speaking group. This group was split into 2 groups of 85 students per group, which were then split into 8 groups. The authors decided that Project 1 should be presented to the Afrikaans group because the smaller number of students lent itself more effectively to the tasks the project required the students to perform.

Project 2 was implemented with the 390 students of the English-speaking group, which were split into 2 groups of 195 students per group. They were split into 25 groups of 8 students per group. Step 2 for Projects 1 and 2 will now be discussed.

\subsubsection{Step 2: implementing the predetermined plan}

5.1.2.1 Project 1. The second 2-hour lecture was presented by the students themselves. During the first lecture, in which the Afrikaans students had been divided into groups of between eight and ten individuals, each group had received a specific general control in the IT environment to research. Each small group had to prepare a PowerPoint presentation on their particular general control, to present to the rest of the class. The presentation had to include the following:

- a definition of the control;

- a summary or mind map of the control;

- at least one example of such a control in the workplace; and

- how they would identify the control during the performance of an audit.

This second lecture took place two weeks later, during which the results of the co-operative learning efforts of the small groups were presented to the entire class. The students thus had to find and organise the information regarding the general controls in the IT environment and prepare a PowerPoint presentation and a mind-map on the general controls in the IT environment, all within a period of two weeks. This task was assessed as requiring approximately 4 hours from each student.

5.1.2.2 Project 2. At the end of the first 2-hour lecture, the two English-speaking groups were divided into small groups of eight members. Each student in the group had to do research on one of the eight general controls used in the audit of the IT environment, and, as a group, they had to prepare an internal control questionnaire addressing the eight general controls. To allow the students sufficient time to find and organise the information and to prepare the internal control questionnaires, the second lecture (the simulation of a real life audit) took place two weeks later.

Prior to the start of the second 2-hour lecture, the authors simulated an audit client's IT manager's office inside the lecture hall. On arrival at the lecture hall, students were informed that they had to evaluate the audit client's general controls. One of the authors acted as the audit client's IT manager, and shared general information regarding the 
audit client's IT operations with the students. Active participation by all the students was encouraged, and students were prompted to observe and to enquire about the audit client's general controls, using the internal control questionnaires that they had previously prepared.

The students of each group then pooled and discussed the information they had gathered and approached the "audit client's IT manager" to obtain such additional information as they thought pertinent to the simulation. As all the groups in the class addressed all eight of the general controls in the IT environment, most of the groups had similar questions, and the "audit client's IT manager" unavoidably provided the other groups with most of the answers, whether specifically asked to or not. After the question session a group discussion was convened, during which the simulation was examined and the gaps identified by the "audit client's IT manager" (the questions not asked by the students) were addressed.

After the lecture, each group had to prepare a report assessing the internal control weaknesses and strengths and assemble a poster illustrating the controls in the IT environment.

This project was assessed as requiring each student to spend approximately 1 hour preparing the internal control questionnaire, and approximately 3 hours preparing the report and the poster.

5.1.3 Step 3: observing the effects of the plan during its implementation. Keeping in mind the limitations of action research, particularly the risk of excessive generalisation and the possible manipulation of the research process, (Mouton, 2012), data were collected from multiple sources using diverse methods (Herington and Weaven, 2008; Hermes, 1999). The authors also wanted a more comprehensive, holistic and contextual portrayal of the perceptions of the different parties involved in the study, thus ensuring valid triangulation of the study's results. The data collection methods included the following:

- the authors' field notes in the form of self-reflections on their experiences of and during the lectures;

- an analysis of the video recordings of the lectures;

- notes and written observations from colleagues who had acted as peer reviewers during the lectures;

- notes and reflections on general discussions that took place during a debriefing meeting between the authors and the peer reviewers; and

- anonymous questionnaires completed by students who had attended the lectures to provide the authors with quantifiable perceptions of these non-standard lectures, in addition to qualitative data (Appendix 1 contains Project 1's questionnaire and Appendix 2 contains Projects 2's questionnaire).

5.1.4 Step 4: reflecting on the effects. The authors, the peer reviewers and the students all provided reflections that covered both sessions (Du Toit, 2012). The authors were assisted in preparing their final reflections by referring to the video recordings of the lectures. In addition, the authors made use of their notes made before, during and after the sessions; the review notes received from the peer reviewers; the feedback provided by the peer reviewers in the debriefing meeting; and the questionnaires completed by the students (Cresswell, 2013; Jick, 1979). The use of multiple sources of evidence enabled the results of the study to be meaningfully triangulated (Cresswell, 2013; Jick, 1979). 
This in turn enhanced the authors' ability to evaluate the effectiveness of their efforts to involve students during auditing lectures, as well as to determine whether they had managed to assist students to develop appropriate professional skills.

\subsection{The authors' reflections}

What follows is a conflation of the two authors' reflections on Cycle 1 of the process, as appropriate to the aim of the paper, and collected under the headings Before action, In action and After action.

5.2.1 Before action. During the planning of the two projects, the authors were faced with numerous challenges. The first challenge was the realisation that transforming a lecturer-centred approach to a student-centred approach required a bigger mind-shift than had originally been anticipated. Adding to this challenge was the realisation that this transformation needed to take place in a large class environment. The authors had already realised that they had to find teaching practices that went beyond their normal ways of presenting information (students attending the lectures are now predominantly "generation Y" in attitude and approach to learning) (Booysen, 2013; Feiertag and Berge, 2008; Kane, 2013; Slabbert et al., 2009), by which it is meant that they prefer interactive involvement to passive observation, even if their participation preference is predominantly filtered through their mobile communication devices.

The second challenge faced by the authors was to escape from the comfort zone of their carefully constructed teaching philosophies and to implement the planned projects in the real world and in real time. Nevertheless, the natural tendency of human beings to resist change was finally overcome (Slabbert et al., 2009).

The following extract from the notes of one of the authors describes her feelings on the morning of the first "non-standard" lecture:

Today is the day, I am quite nervous and totally out of my comfort zone. I do not know what to expect from the lecture or the students, but in a strange way I am looking forward to the lecture.

5.2.2 In action. During their lectures, both the authors identified that they were not fully in control of the situation. Habit and "accepted" forms of lecture-room management and etiquette were useless as guides, as the students were being actively encouraged to participate in the sessions, something neither they nor the authors were used to. Now the students had been given control of a learning opportunity. In addition, they had been encouraged to make their own sense of new information (Biggs, 2000; Doolittle and Camp, 1999; Killen, 2010; Samkin and Francis, 2008; Steffe and Gale, 1995). An element of controlled chaos was present as, in a student-centred learning environment, the lecturer becomes just one more resource available to the students: direct control regarding what and how the students learn has, to all intents and purposes, been relinquished (Killen, 2010).

The authors are now prepared to admit that they were pleasantly surprised by how well prepared the students were. They came to the lectures apparently intending to extract maximum value from the situation, and the feeling of pride they had in their products (PowerPoint presentations, internal control questionnaires and posters) was palpable.

5.2.3 After action. During informal discussions with the students after the lectures, many students commented on the positive value these lectures had added to their 
learning processes, and indicated that they had enjoyed the interactive approach. The authors realised that the relative success of these lectures lay in the fact that they had given the students an opportunity to become actively involved in the learning process, despite the great number of students in the classes.

\subsection{Peer reviewers' reflections}

The peer reviewers observed that the students had been exposed to group work, a key skill they need when they enter full time employment (Barac, 2009; Bui and Porter, 2010; Hall et al., 2007). However, it was also recognised that there was a weakness in these projects, in that students could choose their own group members. This resulted in almost all the groups being of friends. This is an area that needs to be addressed before these projects can be "rolled out", particularly because it is unlikely that there will be many familiar faces initially, once students graduate. In fact, in public practice, they are likely to be faced with a new group of audit colleagues on every audit.

With regard to the group discussions, the peer reviewers indicated that dividing students into groups had worked well. It appeared that the students had enjoyed the group interaction as each one had assumed exclusive responsibility for their own topic (Aziz and Hossain, 2010; Ballantine and Larres, 2009; Ballantine and Larres, 2007; Johnson and Johnson, 1987; Kunkel and Shafer, 1997). This forced all the group members to participate, giving both shy and extrovert students an equal opportunity to participate, thereby encouraging the development of essential, but non-academic professional skills (Barac, 2009; Boritz and Carnaghan, 2003; Palmer et al., 2004).

For Project 1 specifically, the peer reviewers noted that, in general, the presenters (students) were well prepared, but that some of the presentations were very long. In addition, the reviewers noted that a significant number of students had quoted verbatim from the source material provided initially. This issue needs to be addressed outside of the auditing classroom, as plagiarism is not generally tolerated. In addition, students showed that they also needed to be briefed on the basic principles of designing a PowerPoint presentation. Finally, reviewers advised that presentations should be subject to strict time limits.

The peer reviewers commented that Project 2 appeared to have been an effective initiative as student participation had been energetic and interactive. The peer reviewers' overall conclusion was that they were impressed by the skills and creativity that some of the students had displayed, and that the projects had added significant value to the students' learning experiences.

\subsection{Student feedback}

Questionnaires were completed during the first classes after the projects had taken place. As has been noted by Paisey and Paisey (2005), a better response is obtained when the students complete questionnaires in class. (Prior ethical clearance had been obtained for the completion of the questionnaires, and this was communicated to the students: completion was voluntary.) The goal of the questionnaires was to obtain usable insights into the views of the students to improve the projects.

The questionnaire for Project 1 was peer-reviewed by colleagues in the fields of auditing and education, and their suggestions and recommendations were implemented before the questionnaire was presented to students for their feedback. The questionnaire contained both closed and open-ended questions. A total of 114 questionnaires were 
completed, yielding a 67 per cent response rate. The student feedback is summarised in Table I.

Fifty-seven per cent of the respondents indicated that their understanding of the general controls had improved because of their active involvement in this project, although only 45 per cent indicated that it had helped them to apply the theoretical knowledge in practice. Despite these relatively positive views, only 38 per cent considered this to be an effective teaching method. Furthermore, in contrast to the majority of students surveyed in earlier studies who had reported positive support for this method (Booysen, 2013; Feiertag and Berge, 2008; Kane, 2013; Slabbert et al., 2009), only 29 per cent of the current students indicated that this type of hands-on project should be used more often.

Less controversially, this co-operative learning approach was perceived by 44 per cent of the students to have contributed to the development of their logical problem-solving skills, and to their ability to identify and address problems in general. These findings confirm the findings of Barac (2009), Bui and Porter (2010) and Hall et al. (2007).

The questionnaire for Project 2 was based on a questionnaire used in a study conducted by Rudman and Terblanche (2011) on the use of practical role-play as an extension to theoretical audit education. This questionnaire contained both closed- and open-ended questions. The modified questionnaire was also peer-reviewed by colleagues in the auditing and education fields before being distributed. In total, 254 students completed this questionnaire, yielding a 65 per cent response rate. The students' feedback regarding Project 2, and most pertinent to this study, is summarised in Table II.

Table I. Students' feedback regarding Project 1

$$
\begin{array}{ccccc}
\text { Project } 1 & & \\
N=170 \text { students, Response rate }=67 \% \\
\text { Strongly } & \text { Disagree } & \text { Neutral } & \text { Agree } & \text { Strongly } \\
\text { disagree (\%) } & (\%) & (\%) & (\%) & \text { agree }(\%)
\end{array}
$$

The cooperative learning approach through the presentation of the general controls in the computer environment, helped me to [...]

Improve my understanding of the general controls in the computer environment Bridge the gap between theory and the practical application thereof

Think in a logical way when faced with a question of the general controls in the computer environment Improve my skills to identify risks and weaknesses in the general control in a specific scenario

I would rate cooperative learning as [...] An effective teaching method

A teaching method that should be used more often in teaching other auditing topics A teaching method that wasted my time

$\begin{array}{rrrrr}4 & 12 & 27 & 39 & 18 \\ 6 & 24 & 25 & 29 & 16 \\ & & & & \\ 7 & 23 & 26 & 33 & 11 \\ & & & & \\ 5 & 18 & 33 & 33 & 11 \\ & & & & \\ 7 & 23 & 32 & 24 & 14 \\ 12 & 32 & 27 & 18 & 11 \\ 21 & 21 & 27 & 23 & 8\end{array}$


Table II. Students' feedback regarding Project 2

Project 2
Questions

Did the practical real-life simulation contribute to your learning of the subject-matter discussed in the theory lectures?

Do you expect that this practical real-life simulation will enhance your ability to answer Auditing papers, in particular if the questions asked cover the same work as the practical real-life simulation?

Would you want to do another practical real-life simulation in relation to other sections of your Auditing syllabus?

\begin{tabular}{lcccc}
\hline Statements & $\begin{array}{c}\text { Strongly } \\
\text { disagree }(\%)\end{array}$ & $\begin{array}{c}\text { Disagree } \\
(\%)\end{array}$ & $\begin{array}{c}\text { Agree } \\
(\%)\end{array}$ & $\begin{array}{c}\text { Strongly } \\
\text { agree }(\%)\end{array}$ \\
\hline
\end{tabular}

I learnt and remembered more from the practical real-life simulation than I would have through any other teaching methods, such as work assignments, theory classes, etc.

This experience will help me when I work in my future job

I learnt something new from the practical reallife simulation

I believe that I learned non-academic skills from the practical real-life simulation via observation or participation I would not have learnt in a theory class or text book

$\begin{array}{llll}3 & 15 & 57 & 25 \\ 4 & 18 & 57 & 21 \\ 3 & 11 & 56 & 30 \\ 3 & 18 & 52 & 27\end{array}$

The practical, real-life simulation was perceived by 86 per cent of the students as having contributed to their understanding of the subject matter, and this supports the findings of Massey et al. (2002) and Rudman and Terblanche (2011). Sixty-six per cent of students indicated that they would like another practical real-life simulation to form part of their auditing syllabus, confirming the findings of Booysen (2013); Feiertag and Berge (2008) and Kane (2013). The practical real-life simulation was perceived by 78 per cent of the students to be likely to have assisted them in their future jobs, and 86 per cent indicated that they learned something new, both response levels confirming the findings of Massey et al. (2002) and Rudman and Terblanche (2011). Seventy nine per cent of the students indicated that they believed they had developed non-academic skills from their participation in the practical real-life simulation, again confirming the findings of Rudman and Terblanche (2011) and Wessels and Steenkamp (2009).

5.4.1 Comments by students on both the initiatives. According to the students, there were advantages and disadvantages arising from having participated in the projects, as can be seen from the comments below (taken from the completed students' questionnaires for both the projects):

We were hands-on involved in the lecture. We worked through the part that we had to prepare for the lecture in detail and knew exactly what it entailed. It changed the daily routine and made it interesting. 
Students had the opportunity to go and do a project by themselves. This is an effective way of learning.

Groups were too big. All students could not give the effective input to the project so that they could learn.

It takes a lot of time.

\subsection{The second cycle - 2013}

5.5.1 Step 1: planning to solve a problem or implement a predetermined plan or process. After careful analysis of the reflections of the authors, peer reviewers and the students, changes were made to the projects (Carr and Kemmis, 1986; Zubert-Skeritt, 1992) i n preparation for the second action research cycle. The changes and the reasons for the changes are indicated in Table III.

5.5.2 Step 2: acting to implement the predetermined plan. The adjusted project was to be implemented for a new group of students, albeit from a similar demographic and academic background to the participants in the first action research cycle. Project 2 from the first research cycle formed the core of the revised project, modified by the changes shown in the table above. The responsibility to obtain an understanding of the IT environment had been given to the students themselves, and because they had to prepare the internal questionnaire, the approximate time allocation for this task was assessed at about 3 hours.

5.5.3 Step 3: observing the effects of the planned action. The data collection methods used for the first action research cycle were again used in the second action research

Table III. Changes and reasons for changes to the Cycle 1 projects

Change

Project 1 would not be repeated; Project 2 would be used for both groups

A conventional lecture-format briefing to the students on the IT environment to be replaced. Students to assume this responsibility

At the end of the simulation, present a lecture summarising the theory underpinning the IT environment

It was decided to drop the design of a poster illustrating the IT general controls from future projects
Reason for the change

The purpose of the initiatives was to enhance student participation and skills development. The results from Project 1 indicated that only $29 \%$ of students felt that this type of hands-on project should be used more often, while $66 \%$ of students indicated that Project 2 should form part of their auditing syllabus Project 1 was perceived by only $44 \%$ of the students to have contributed to the development of cooperative learning skills, whilst $79 \%$ of the students participating in Project 2 indicated that they had developed similar non-academic skills To complete the move away from a lecturer-centred approach

To ensure that the students identify and understand the core concepts and to address any questions or issues that had not been (clearly) dealt with during their presentations

This caused practical and administrative issues in the previous cycle, particularly regarding marking 
cycle. Project 2's student questionnaire was adjusted to address the changes listed above and administered at the end of Project 2 in Cycle 2.

5.5.4 Step 4: reflecting on the effects. Reflection is the golden thread of action research (Du Toit, 2012). The reflections of the authors, peer reviewers and students on their participation in the second action research cycle are discussed next.

\subsection{The researcher' reflections on the process}

5.6.1 Before action. The authors felt that they were now entering familiar territory. Despite this, there was once again a sense of uncertainty, centred this time on whether the students would in fact have prepared for the class as instructed.

5.6.2 In action. The authors were surprised (and relieved) at how well the students had in fact prepared for the lecture; there was wholehearted student participation and involvement throughout the period. The following quote from the notes of one the authors describes how well the students were prepared:

I had to think on my feet the whole time! The students asked such relevant and sometimes very interesting and technical questions. I loved the way the students started interacting not only with me as the IT manager of the firm, but also with one another.

The positive energy could be felt during the lecture and it looked as if the students really enjoyed the session, corroborating a feature noted by earlier researchers (Biggs, 2000; Doolittle and Camp, 1999; Killen, 2010; Samkin and Francis, 2008; Steffe and Gale, 1995).

5.6.3 After action. It was noted how much easier the learner-centred simulation had proceeded (compared with Project 2 of the first cycle). The substance and relevance of the students' questions showed that they were thoroughly prepared for this lecture.

\subsection{Peer reviewers' reflections}

The peer reviewers observed that it had been a well-prepared initiative and that they had enjoyed the lecture. They commented that they had not seen students so passionate about an audit topic in a long time. The students' conversations with the peer reviewers showed that they enjoyed this type of "real-life" simulation and had expressed their desire to have more lectures conducted in this way.

On the negative side, the peer reviewers felt the loss of energy during the formal closing lecture (the return to the lecturer-centred approach), but also agreed that a formal conclusion was necessary.

\subsection{Student feedback}

The same basic questionnaire that had been used for Project 2 during Cycle 1 was used for the revised project in Cycle 2 (with adjustments necessitated by the changes discussed above) (Appendix 2). In total, 308 students completed the questionnaire, yielding a 55 per cent response rate. The students' feedback regarding the revised project, and relevant to this study, is summarised in Table IV.

The general feedback received from the students regarding the practical real-life simulation was once again positive. The responses correlate positively with the first cycle's feedback, which suggest that the practical real-life simulation contributed towards the students' learning of the subject matter (Cycle 2-8 7 p e r cent, Cycle 1 -86 per cent). This confirms the findings of Massey et al. (2002) and Rudman and 
Table IV. Students' feedback regarding the revised project

\begin{tabular}{|c|c|c|c|c|}
\hline \multicolumn{3}{|l|}{ Questions } & Yes $(\%)$ & No $(\%)$ \\
\hline $\begin{array}{l}\text { Did the practical real-life simulation contribute to } \\
\text { subject-matter discussed in the theory lectures? } \\
\text { Do you expect that this practical real-life simulati } \\
\text { to answer Auditing papers, in particular if the que } \\
\text { same work as the practical real-life simulation? } \\
\text { Would you want to do another practical real-life s } \\
\text { other sections of your Auditing syllabus? }\end{array}$ & $\begin{array}{l}\text { our learning of } \\
\text { will enhance } \\
\text { tions asked co } \\
\text { aulation in rela }\end{array}$ & $\begin{array}{l}\text { he } \\
\text { our ability } \\
\text { ion the }\end{array}$ & $\begin{array}{l}78 \\
74\end{array}$ & $\begin{array}{l}13 \\
22 \\
26\end{array}$ \\
\hline Statements & $\begin{array}{c}\text { Strongly } \\
\text { disagree }(\%)\end{array}$ & $\begin{array}{c}\text { Disagree } \\
(\%)\end{array}$ & $\begin{array}{c}\text { Agree } \\
(\%)\end{array}$ & $\begin{array}{l}\text { Strongly } \\
\text { agree }(\%)\end{array}$ \\
\hline $\begin{array}{l}\text { I learnt and remembered more from the practical } \\
\text { real-life simulation than I would have through } \\
\text { any other teaching methods, such as work } \\
\text { assignments, theory classes, etc. } \\
\text { This experience will help me when I work in my } \\
\text { future job } \\
\text { I learnt something new from the practical real- } \\
\text { life simulation } \\
\text { I believe that I learned non-academic skills from } \\
\text { the practical real-life simulation via observation } \\
\text { or participation I would not have learnt in a } \\
\text { theory class or text book }\end{array}$ & 4 & 10 & 59 & 19 \\
\hline
\end{tabular}

Terblanche (2011). During Cycle 2, 74 per cent of the students indicated that another practical real-life simulation should form part of their auditing syllabus, thus confirming the findings of Booysen (2013), Feiertag and Berge (2008) and Kane (2013).

The practical real-life simulation was perceived by 80 per cent of the students (78 per cent in Cycle 1) as likely to assist them in their future jobs, and 88 per cent (86 per cent in Cycle 1) indicated that they learned something new, thus confirming the findings of Massey et al. (2002) and Rudman and Terblanche (2011). Seventy eight per cent of the students indicated that they had developed non-academic skills from the practical real-life simulation (79 per cent from Project 1), again confirming the findings of Rudman and Terblanche (2011) and Wessels and Steenkamp (2009).

5.8.1 Comments by students on this initiative. According to the students, there were advantages and disadvantages arising from this project, as can be seen from the comments below (taken from the students' completed questionnaires):

Seeing the process as a whole and not as separate sections leads to good integration.

This was very time-consuming.

Questions need to be asked to the client therefore you learn how to ask adequate questions in order to get information you need. 
Practical examples help me to understand the topic.

Participation and interaction were a great benefit.

It gave me confidence to participate in class.

After the completion of the two action research cycles, it is clear, based on the reflection of all the parties involved, that "non-standard" teaching practices can be implemented successfully. The initiatives, in general, were well received, and the feedback and data gathered can now be used to improve the next action research cycle.

\section{Conclusion}

There are numerous changes occurring in the accounting education environment, many that challenge traditional teaching practices. These challenges include meeting the requirements and expectations of professional bodies, and adjustments to communication styles necessitated by the need to connect with a new generation of students. In addition, there are demanding changes becoming apparent in the purely academic environment. This agglomeration of changes and challenges is more or less compelling accounting academics to explore innovative practices for the teaching of technical knowledge and professional skills to this new and attitudinally highly distinctive generation of students.

The aim of this paper was to report on the development and implementation of two student-centred teaching approaches, not usually thought to be appropriate for large group situations. Two student-centred projects were implemented in the discipline of auditing, at a South African residential university. The one project involved presentations prepared by the students in a co-operative learning environment, and the other project was a simulation of an aspect of a real-life audit environment. The findings from both the projects suggested that the students enjoyed the projects, and that they had developed professional skills during their participation in the projects. The authors successfully used the action research methodology to incorporate changes, enforced by the challenges described above, into their current teaching practices.

Limitations associated with this study are that it was conducted at only one South African university, and that it was in a specific and technical topic within the single field of auditing. The study also did not measure whether deep or surface learning had taken place. However, its purpose was only to reflect on the use of student-centred approaches in large class environments, and to evaluate the practical implementation thereof. As various factors contribute to learning it is also not possible to report on whether positive changes to students' normal learning processes have been achieved as a result of the initiatives. Suffice to say (for now) that for three class sessions, students appeared to be more fully engaged with the subject material than educators generally observe during "normal" lecturer-focussed classes.

Suggestions for future research include the implementation of other student-centred approaches to teaching other auditing topics, and in associated disciplines, and to encourage accounting academics, in other disciplines such as financial accounting, tax and management accounting, to move from a lecturer-centred approach to a student-centred approach. 


\section{References}

Abeysekera, I. (2006), "Issues relating to designing a Work-Integrated Learning (WIL) program in an undergraduate accounting degree program and its implications for the curriculum", Asia Pacific Journal of Cooperative Education, Vol. 7 No. 1, pp. 7-15.

Altrichter, H., Kemmis, S., McTaggart, R. and Zuber-Skerrit, O. (2002), "The concept of action research”, The Learning Organization, Vol. 9 No. 3, pp. 125-131.

Aziz, Z. and Hossain, A. (2010), "A comparison of cooperative learning and conventional teaching on students' achievement in secondary mathematics", Procedia Social and Behaviour Sciences, Vol. 9 No. 1, pp. 53-62.

Baeten, M., Kyndt, E., Struyven, K. and Dochy, F. (2010), "Using student-centred learning environments to stimulate deep approaches to learning: factors encouraging or discouraging their effectiveness”, Educational Research Review, Vol. 5 No. 1, pp. 243-260.

Baker, C.R. and Logan, L.B. (2006), "Using action research to promote increased academic success for educationally disadvantaged students”, Global Perspectives on Accounting Education, Vol. 3 No. 1, pp. 1-22.

Ballantine, J. and Larres, P.M. (2007), “Cooperative learning: a pedagogy to improve students' generic skills?”, Education + Training, Vol. 49 No. 2, pp. 126-137.

Ballantine, J. and Larres, P.M. (2009), “Accounting undergraduates' perceptions of cooperative learning as a model for enhancing their interpersonal and communication skills to interface successfully with professional accountancy education and training", Accounting Education: An International Journal, Vol. 18 No. 4, pp. 387-402.

Barac, K. (2009), "South African training officers' perceptions of the knowledge and skills requirements of entry-level trainee accountants", Meditari Accountancy Research, Vol. 17 No. 2, pp. 19-46.

Bassey, M. (1998), “Action research for improving educational performance”, in Halsall, R. (Ed.), Teacher Research and School Improvement, Open University Press, Buckingham.

Biggs, J. (2000), Teaching for Quality Learning at University, Open University Press, London.

Booysen, V. (2013), “Generasie Y verg nuwe benadering”, Beeld Sake 24, 30 Januarie, p. 22.

Boritz, J.E. and Carnaghan, C.A. (2003), “Competency-based education and assessment for the accounting profession: a critical review”, Canadian Accounting Perspectives, Vol. 2 No. 1, pp. $7-42$.

Brew, A. (2003), "Teaching and research: new relationships and their implications for inquiry-based teaching and learning in higher education", Higher Education Research and Development, Vol. 22 No. 1, pp. 3-18.

Bui, B. and Porter, B. (2010), "The expectation-performance gap in accounting education: an exploratory study”, Accounting Education: An International Journal, Vol. 19 Nos 1/2, pp. 23-50.

Carr, W. and Kemmis, S. (1986), Becoming Critical: Education, Knowledge and Action Research, Routledge Farmer, New York, NY.

Cooper, J.L. and Robinson, P. (2000), "The argument for making large classes seems small”, New Directions for Teaching and Learning, Vol. 81 No. 1, pp. 5-16.

Crawford, L., Helliar, C. and Monk, E.A. (2011), “Generic skills in audit education”, Accounting Education: An International Journal, Vol. 20 No. 2, pp. 115-131.

Cresswell, J.W. (2013), Research Design: Quantitative, Qualitative and Mixed Methods Approaches, Sage Publications, Thousand Oaks, CA. 
Cunningham, B.M. (2008), "Using action research to improve learning and the classroom learning environment", Issues in Accounting Education, Vol. 23 No. 1, pp. 1-30.

De Lange, R., Marx, B. and Van der Watt, A. (2013), "Sustainability in education: an evaluation of a new teaching and learning strategy in chartered accountancy studies-a student perspective", Journal of Economic and Financial Sciences, Vol. 6 No. 2, pp. 285-308.

De Villiers, R. (2010), "The incorporation of soft skills into accounting curricula: preparing accounting graduates for their unpredictable futures", Meditari Accountancy Research, Vol. 18 No. 2, pp. 1-22.

Doolittle, P.E. and Camp, W.G. (1999), "Constructivism: the career and technical education perspective", Journal of Vocational and Technical Education, Vol. 16 No. 1, pp. 1-19.

Du Toit, P.H. (2012), Reader for Postgraduate Studies in Professional Development, Facilitating Learning and Assessment, Department of Humanities Education, University of Pretoria, Pretoria.

Elton, L. (2001), "Research and teaching: conditions for a positive link", Teaching in Higher Education, Vol. 6 No. 1, pp. 43-56.

Evans, E., Burritt, R. and Guthie, J. (2010), “Accounting education at a crossroad in 2010", available at: www.charteredaccountants.com.au/academic (accessed 23 March 2014).

Feiertag, J. and Berge, Z.L. (2008), “Training generation N: how educators should approach the Net Generation", Education and Training, Vol. 50 No. 6, pp. 457-464.

French, S. (2009), "Action research for practicing managers", Journal of Management Development, Vol. 28 No. 3, pp. 187-204.

Gabbin, A.L. and Wood, L.I. (2008), “An experimental study of accounting major's academic achievement using cooperative learning groups", Issues in Accounting Education, Vol. 23 No. 3, pp. 391-404.

Gentry, J.W. (1990), "What is experiential learning”, in Gentry, J.W. (Ed.), Guide to Business Gaming and Experiential Learning, Nichols/GP Publishing, East Brunswick, pp. 9-20.

Grulke, W. (2000), Ten Lessons from the Future - 21st Century Impact on Business, Individuals andInvestors,@One Communication, Parklands.

Hall, M., Ramsey, A. and Raven, J. (2007), "Changing the learning environment to promote deep learning approaches in first-year accounting students", Accounting Education: An International Journal, Vol. 13 No. 4, pp. 489-505.

Hand, L. (2001), "Action research - a way forward for accounting educators", Accounting Education presented at the BAA SIG in Accounting Education Conference, 2-4 July, University of Glamorgan, Pontypridd.

Hazelton, J. and Haigh, M. (2010), "Incorporating sustainability into accounting curricula: lessons learnt from an action research study", Accounting Education: An International Journal, Vol. 19 Nos 1/2, pp. 159-178.

Herington, C. and Weaven, S. (2008), "Action research and reflection on student approaches to learning in large first year university classes", The Australian Educational Researcher, Vol. 35 No. 3, pp. 111-134.

Hermes, L. (1999), "Learner assessment through subjective theories and action research", Assessment and Evaluation in Higher Education, Vol. 24 No. 2, pp. 197-204.

Howieson, B., Hancock, P., Segal, N., Kavanagh, M., Tempone, I. and Kent, J. (2014), “Who should teach what? Australian perceptions of the roles of universities and practice in the education of professional accountants", Journal of Accounting Education, Vol. 32 No. 3, pp. 259-275. 
Jackson, R.D.C. and Stent, W.J. (2012), Auditing Notes for South African Students, LexisNexis, Durban.

Jick, T.D. (1979), "Mixing qualitative and quantitative methods: triangulation in action", Administrative Science Quarterly, Vol. 24 No. 4, pp. 602-611.

Johnson, D.W. and Johnson, R.R. (1987), Learning Together and Alone: Cooperative, Competitive and Individualistic Learning, Prentice-Hall, Englewood Cliffs, NJ.

Jove, G. (2011), "How do I improve what I am doing as a teacher, teacher educator and action-researcher through reflection? A learning walk from Lleida to Winchester and back again”, Educational Action Research, Vol. 19 No. 3, pp. 261-278.

Jukes, I. and Dosaj, A. (2006), "Understanding digital children: Teaching and learning in the new digital landscape", Prepared for the Singapore MOE Mass Lecture, The Info Savvy Group, Ahmedabad.

Kane, S. (2013), “Generation Y”, available at: http://legalcareers.about.com/od/practicetips/a/ generation.htm (accessed 3 February 2013).

Kaplan, R.S. (1998), "Innovation action research: creating new management theory and practice", Journal of Management Accounting Research, Vol. 10 No. 1, pp. 89-118.

Kastantin, J. and Novicevic, M. (2008), "Teaching the choir: challenges of a learner-centred simulation", Accounting Education, Vol. 1 No. 2, pp. 209-212.

Kember, D. and Gow, L. (1992), "Action research as a form of staff development in higher education”, Higher Education, Vol. 23 No. 3, pp. 297-310.

Keneley, M. and Jackling, B. (2011), "The acquisition of generic skills of culturally-diverse student cohorts", Accounting Education, Vol. 20 No. 6, pp. 605-623.

Killen, R. (2010), Teaching Strategies for Quality Teaching and Learning, Juta, Claremont.

Kunkel, J.G. and Shafer, W.E. (1997), "Effects of student team learning in undergraduate auditing courses”, Journal of Education for Business, Vol. 72 No. 4, pp. 197-200.

Leitch, L. and Day, C. (2006), "Action research and reflective practice: towards a holistic view", Educational Action Research, Vol. 8 No. 1, pp. 179-193.

Low, M., Samkin, G. and Liu, C. (2013), "Accounting education and the provision of soft skills: implications of the recent NZICA CA Academic requirement changes", E-Journal of Business Education \& Scholarship of Teaching, Vol. 7 No. 1.

McNiff, J. (2002), “Action research for professional development: concise advice for new action researchers", available at: www.jeanmcniff.com/ar-booklet.asp (accessed 23 January 2013).

Massey, D.W., Poli, P.M. and Proctor, R.J. (2002), “The development and evaluation of a team based audit simulation in the introductory auditing course", available at http://aaahq.org/ northeast/abstracts/massey.pdf (accessed 1 September 2014).

Mouton, J. (2012), How to Succeed in Your Master's and Doctoral Studies, Interpak Books, Pietermaritzburg.

Paisey, C. and Paisey, N.J. (2003), "Developing research awareness in students: an action research project explored", Accounting Education, Vol. 12 No. 3, pp. 283-302.

Paisey, C. and Paisey, N.J. (2005), "Improving accounting education through the use of action research", Journal of Accounting Education, Vol. 23 No. 1, pp. 1-19.

Palmer, K.N., Ziegenfuss, D.E. and Pinsker, R.E. (2004), "International knowledge, skills, and abilities of auditors/accountants: evidence from recent competency studies", Managerial Auditing Journal, Vol. 19 No. 7, pp. 889-896. 
Perera, A.S. (2012), "Challenges faced by accounting academics", International Journal of Research in Commerce and Management, Vol. 1 No. 3, pp. 6-8.

Reason, P. and Bradbury, H. (2007), Handbook of Action Research, Sage, London.

Rudman, R.J. and Terblanche, J. (2011), "Practical role-play as an extension to theoretical audit education: a conceptualising aid", The South African Journal of Accountability and Auditing Research, Vol. 11 No. 1, pp. 63-74.

Samkin, G. and Francis, G. (2008), "Introducing a learning portfolio in an undergraduate financial accounting course", Accounting Education: An International Journal, Vol. 17 No. 3, pp. 233-271.

Samkin, G. and Schneider, A. (2014a), "Using university websites to profile accounting academics and their research output: a three country study”, Meditari Accountancy Research, Vol. 22 No. 1, pp. 77-106.

Samkin, G. and Schneider, A. (2014b), "The accounting academic", Meditari Accountancy Research, Vol. 22 No. 1, pp. 2-19.

Slabbert, J.A., de Kock, D.M. and Hattingh, A. (2009), The Brave "New" World of Education: Creating A Unique Professionalism, Juta, Cape Town.

Slavin, R.E. (1996), "Research on cooperative learning and achievement: what we know", Contemporary Educational Psychology, Vol. 21 No. 1, pp. 43-69.

South African Institute of Chartered Accountants (2010), "Competency framework: detailed guidance for academic programmes", South African Institute of Chartered Accountants, Johannesburg.

Steffe, L.P. and Gale, J. (1995), Constructivism in Education, Oxford University, Oxford.

Stork, D. (2003), "Teaching statistics with student survey data: a pedagogical innovation in support of student learning", Journal of Education for Business, Vol. 78 No. 6, pp. 335-339.

Van Wyk, A. (2006), "Action research as a means of course development in higher education: a case study”, South African Journal of Higher Education, Vol. 20 No. 3, pp. 194-208.

Webb, L.A. and Scoular, T. (2011), "Reflection on reflection on reflection: collaboration on action research", Educational Action Research, Vol. 19 No. 4, pp. 469-487.

Wessels, P.L. and Steenkamp, L.P. (2009), “An investigation into students' perceptions of accountants”, Meditari Accountancy Research, Vol. 17 No. 1, pp. 117-132.

Wolmarans, H.P. (2005), "Business simulations in financial management courses: are they valuable to learners?”, Meditari Accountancy Research, Vol. 13 No. 1, pp. 121-133.

Wynder, M. (2004), "Facilitating creativity in management accounting: a computerised business simulation", Issues in Accounting Education, Vol. 25 No. 3, pp. 527-546.

Zubert-Skeritt, O. (1992), Action Research in Higher Education, Kogan Page, London. 


\section{Appendix 1}

Annexure A

A questionnaire to determine the student's perspective on cooperative learning as a teaching method.

For each of the sections below, place a $\checkmark$ in the relevant box, unless requested to do otherwise.

Please indicate to what extent you agree or disagree with the following statements.

The cooperative learning approach, through the presentation of the general controls in the computer environment, helped me to:

\begin{tabular}{|c|c|c|c|c|c|}
\hline & $\begin{array}{l}\text { Strongly } \\
\text { Disagree }\end{array}$ & Disagree & Neutral & Agree & $\begin{array}{l}\text { Strongly } \\
\text { Agree }\end{array}$ \\
\hline $\begin{array}{l}1 \text { improve my understanding } \\
\text { of the general controls in } \\
\text { the computer environment. }\end{array}$ & & & & & \\
\hline $\begin{array}{l}2 \text { bridge the gap between } \\
\text { theory I study and the practical } \\
\text { application thereof; }\end{array}$ & & & & & \\
\hline $\begin{array}{l}3 \text { think in a logical and in } \\
\text { a systematic way when faced } \\
\text { with a question of the general } \\
\text { control in the computer } \\
\text { environment. }\end{array}$ & & & & & \\
\hline $\begin{array}{l}4 \text { improve my skills to } \\
\text { identify risks and weaknesses } \\
\text { in the general control in a } \\
\text { specific scenario. }\end{array}$ & & & & & \\
\hline
\end{tabular}

I would rate cooperative learning as:

\begin{tabular}{|l|l|l|l|l|l|}
\hline & $\begin{array}{l}\text { Strongly } \\
\text { Disagree }\end{array}$ & Disagree & Neutral & Agree & $\begin{array}{l}\text { Strongly } \\
\text { Agree }\end{array}$ \\
\hline $\begin{array}{l}1 \text { an effective teaching } \\
\text { method; }\end{array}$ & & & & & \\
\hline $\begin{array}{l}2 \text { a teaching method that } \\
\text { should be used more often in } \\
\text { teaching other auditing topics; }\end{array}$ & & & & & \\
\hline $\begin{array}{l}3 \text { a teaching method that } \\
\text { wasted my time. }\end{array}$ & & & & & \\
\hline
\end{tabular}

What did you like most about cooperative learning as a teaching method?

What did you like least about cooperative learning as a teaching method? 


\section{Appendix 2}

Practical real-life simulation feedback questionnaire

\section{Annexure B}

\section{Instructions:}

In this questionnaire you will be asked for your opinion on various issues. In answering these questions we are interested in your opinions about the usefulness of the practical real-life simulation which was conducted during formal lectures as learning and teaching tool. Your views will contribute to the on-going improvement of teaching auditing, therefore please use this opportunity responsibly. Your responses will be treated as strictly confidential.

Please complete the questions below by either selecting the most applicable answer (by marking it with $a \times$ or $a \checkmark$ ) or completing the spaces provided.

Did the practical real-life simulation contribute to your learning of the subject-matter discussed in the theory lectures?

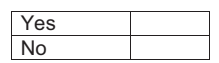

Do you expect that this practical real-life simulation will enhance your ability to answer Auditing papers, in particular if the questions asked cover the same work as the practical real-life simulation?

\begin{tabular}{|l|l|}
\hline Yes & \\
\hline No & \\
\hline
\end{tabular}

Would you want to do another practical real-life simulation in relation to other sections of your Auditing syllabus?

\begin{tabular}{|l|l|}
\hline Yes & \\
\hline No & \\
\hline
\end{tabular}

State whether you agree or disagree with the following statements on the project as part of the learning process. Please choose from the following scale to indicate the strength of your preference for each question and mark the box on the scale next to the question:

\begin{tabular}{|l|l|l|c|c|}
\hline & $\begin{array}{c}\text { Strongly } \\
\text { disagree } \\
\text { 1 }\end{array}$ & $\begin{array}{c}\text { Disagree } \\
\text { Agree }\end{array}$ & $\begin{array}{c}\text { Strongly } \\
\text { agree } \\
\mathbf{4}\end{array}$ \\
\hline $\begin{array}{l}\text { I learnt and remembered more from the } \\
\text { practical real-life simulation than I would } \\
\text { have through any other teaching methods, } \\
\text { such as work assignment, theory classes, } \\
\text { etc. }\end{array}$ & & $\mathbf{2}$ & & \\
\hline $\begin{array}{l}\text { This experience will help me when I work in } \\
\text { my future job. }\end{array}$ & & & & \\
\hline $\begin{array}{l}\text { I learnt something new from the practical } \\
\text { real-life simulation. }\end{array}$ & & & & \\
\hline $\begin{array}{l}\text { I believe that I learned non-academic skills } \\
\text { from the practical real-life simulation via } \\
\text { observation or participation I would not have } \\
\text { learnt in a theory class or text book. }\end{array}$ & & & & \\
\hline
\end{tabular}

Based on your experience, list the three most important benefits (advantages) arising from the practical real-life simulation, as a teaching and learning tool. 
Based on your experience, list the three most significant constraints (disadvantages) arising from the practical real-life simulation, as a teaching and learning tool.

Based on your experience, list the three most important benefits (advantages) arising from the practical real-life simulation, as a teaching and learning tool.

\section{Corresponding author}

Marina Kirstein can be contacted at: marina.kirstein@up.ac.za 